\author{
Jacek CHMIELEWSKI ${ }^{1}$
}

\title{
GUIDELINES FOR THE CONSTRUCTION OF THE IT ROAD SAFETY MANAGEMENT SYSTEM
}

\begin{abstract}
The article presents the role, need and idea of implementing an IT system to manage road safety, which is a proposal of the practical implementation of the Gambit programme elements prepared for the Kujawsko-Pomorskie Voivodeship. The usefulness of constructing the system has been presented, together with its users, the proposed content and possibility of its funding. The whole article has been summarised by outlining the opportunities and threats that may occur in the course of system implementation.
\end{abstract}

Keywords: traffic engineering, IT system, road safety

\section{Sources of Road and Traffic Safety Data}

Both in Poland and abroad, issues of road safety deals with a number of institutions and organizations, among which first of all local and central government units (including city councils and road authorities), the police and the design and research offices should be mentioned. The basis for the work and research related to traffic, especially on the road safety, should be widely available and reliable databases. In the era of universal access to high-speed internet network, either from the computer stations and mobile devices, the most common and simplest form of presentation of data collected in databases are web portals, which, thanks to the readability of this content and intuitive user interface, enable easy access to information almost for all user. Nowadays widely available and free databases typically enable to obtain overall statistics in the field of transport, road infrastructure or road safety. They concern worldwide, as presented in the IRTAD web database [1], the European Union, as well as the country's internet portals, among others, The National Road Safety Council, Polish Road Safety Observatory, the Police Headquarters. Data presented in these sources are aggregated, showing statistical information in the field of infrastructure and road traffic (ex. the length of the national road network), traffic incidents recorded in the given period and the selected area (ex. in the year, monthly), and also the nature and observed trends in

\footnotetext{
${ }^{1}$ Jacek Chmielewski, University of Science and Technology, Department of Road and Transport Engineering, jacek-ch@utp.edu.pl
} 
recent years. In some of such databases it is also possibility to find a number of articles on new standards and transportations solutions, as well as good practices in the implementation of new design solutions or traffic organization. From the point of view of measures to improve road safety, as well as research on these issues data presented this way are far too poor. They are missing for a number of details about the circumstances of the registered individual road incidents, their precise location and participants. Therefore, some road authorities [2] build their own databases in the field of transport infrastructure, road signing and marking or/and data on traffic incidents - accidents and, in selected cases, collisions. These databases usually are databases with restricted access (usually for a selected group of employees of a road authorities), and their use is often limited to legal actions related to the obligatory roads registry and annual statistics transmitted to the General Directorate for National Roads and Motorways [3]. At the same time in Article 7 of the Directive of the European Parliament and of the Council [4], the European Commission prescribes road authorities should run reports on each case of fatal accident and conducting calculations social costs of both the case of fatal and serious road accident, so it is necessary to collect data about these accidents. This indicates, therefore, that data on road accidents (or more - on all traffic incidents) should be stored by all road authorities.

Selected research offices and institutions engaged in road safety improvement activities work in a similar way as road authorities. For the purposes of their own analysis and studies they usually collect a number of details data including, among others information about traffic incidents, infrastructure, traffic etc. Data for these databases usually come from a variety of sources (road authorities, police, insurance companies), and getting their consistency requires a lot of work.

At the same time, both in Poland and in the world, there is a lack of common available and free databases covering all above mentioned to-date data in the form of detailed enough to become a credible source of information for research and work in the field of road safety management .

\section{The Need and Targets of Creating the IT System}

The rapid development of information technologies and IT systems causes fast access to latest data of high quality seems to be indispensable. Therefore, it is necessary to establish IT systems that make it possible to fast collect and process data concerning a series of daily life issues, including the matters related to the broad concept of human safety [5]. Considering the fact that almost all of local residents have to travel by road transport every day, road safety is one of the key element of this safety. In this respect, the basic role of a constructed and maintained IT system is the management of road safety all over the country, in voivodeships, poviats, towns and gminas. The basic target of the presented IT system is possible fast and easy access by individual entities and organizations involved in road safety to: 
a. data necessary in the road safety management process or in all activities related to this process (for example the number of road incidents);

b. all auxiliary materials within the broad education in road safety, including education at schools, personnel training, courses for drivers, etc. (templates of leaflets, advertisements, programmes that promote safe behaviour in traffic, among the youngest users of road infrastructure, drivers, and the elderly persons);

c. auxiliary materials within planning, designing, building and maintaining road infrastructure;

d. results of current road safety analyses, including reports on the road safety status showing the past and present condition of road safety;

e. results of controls and monitoring of activities for road safety;

f. results of specialist analyses concerning road safety (as a rule prepared for a specific department of road authorities by road safety experts).

An additional role to be played by such IT system should be the function of fast and simple access to important information in the area of road safety for all non-profit organizations that are not directly involved in road safety and to individuals, especially the local communities. Every citizen who uses road infrastructure and travels along the streets and roads every day, either as a pedestrian, a passenger in a car or by other means of transport or as a driver, is exposed to risk that result from the common conflicts between different users of transport infrastructure, its imperfections, failures of its elements (e.g. lighting, traffic signal etc.) as well as one's own imperfections and sometimes ignorance. Moreover, it is worth remembering that most such risks may cause just some material losses, as a consequence of traffic collisions. However, there are some potential risk to health and life of citizens. Therefore, every resident should have fast access to information related to his own safety as well as the methods and means of its enhancement, methods of preventing hazards in transport, facilitating his family members in safe travels, methods of action in the cases of the incidents occurrence or a requirement to administer emergency first aid.

In view of the above mentioned assumptions, it is necessary the presented IT system will fulfil the following four key characteristics [6]:

a. its implementation and operation will be cheap;

b. it will be easily accessible;

c. its operation will be simple and user-friendly;

d. it will be always reliable and up-to-date.

In the age of the intense development of IT and the general access to computers and mobile devices, which operate as portable computers (tablets or mobile phones), in view of constantly developing techniques of information sharing in wireless networks and non-stop internet access, fast access to information is becoming something obvious and necessary. People tend to stop buying books and newspapers, instead reading news distributed on Internet portals, often called web portals, several times a day. A modern man who looks for information will first of all use the vast database of internet, where access to such resources is gained usu- 
ally with a mobile phone that is available almost to everyone. Therefore, it seems obvious that the IT system of road safety management, being also an information portal on road hazards, should play a similar function. The portal, by eliminating the requirements in the form of purchasing specialist database software, fulfils the first of the assumed characteristics - the low implementation and operational costs. In such a portal the easy use should be guaranteed by the free of charge and quick access to basic information within any and all matters related to the broadly understood safety in transport, especially in the mode of transport that is most common at present, i.e. road transport. A simple, transparent, and intuitive structure of the portal, which should copy solutions proven in the most popular information portals (tvn24.pl, cnn.com) and social media (facebook.com, twitter.com), based on the map system (Google Maps, OpenStreetMap), that enables fast localization in space, provides the easy operation, and thus encourages users to access the database. The above-mentioned elements should be complemented by the fact that information available should be up-to-date and reliable. It is beyond doubt that the most visited websites are those where news are updated often - as a consequence, a portal attracts a group of its users. Another important feature of popular websites is the function of expressing one's opinion by users .

\section{Administrator and Users of the IT System}

Professional hardware and software accompanied by the top level administrator is necessary to ensure the safety and reliability of the system. Taking into account the supra-local nature of the presented IT solution, it is assumed the system should be located in the in depended unit - the Provincial Road Safety Centre. In the very beginning some funds will be necessary to organize the unit, purchase of equipment and software and to create the initial form of database. It is expected, however, that over time the system becomes self-funding, and a primary source of income will be a fee sharing data resources (e.g. related to the design of road infrastructure) and advertising posted on the portal.

It goes without saying that for a specialist internet portal, such as the road safety management system, it is much more difficult to gather permanent users than in the case of news portals or social media (Facebook, Twitter etc.). To obtain permanent users, it is necessary to provide the content that will fulfil the expectations of a specific group of its users. Therefore potential portal users should be identified first. The groups of potential users may include (fig.1):

a. organizations responsible for road safety in the country, voivodeships, poviats, towns and gminas;

b. local government authorities - presidents of cities, poviat starosts, mayors and voyts, councillors, whose basic statutory obligations include the provision of safety to their local communities, being also a tool in political competition and in the presentation of their work;

c. local residents in specific areas, for whom their own safety and the safety of 
their families is a top priority, in particular - their children;

d. social campaigns that take measures to improve the conditions, comfort, and safety of local communities;

e. media that inform their receivers of the present situation in transport;

f. pupils and students who learn matters related to transport, including safety in transport, and prepare different thematic projects;

g. students of driving courses and young drivers who learn how to behave correctly in traffic and avoid errors that lead to road incidents,

h. planners and designers who want to check the conformity of new design solutions in transport, good practices in designing and planning etc;

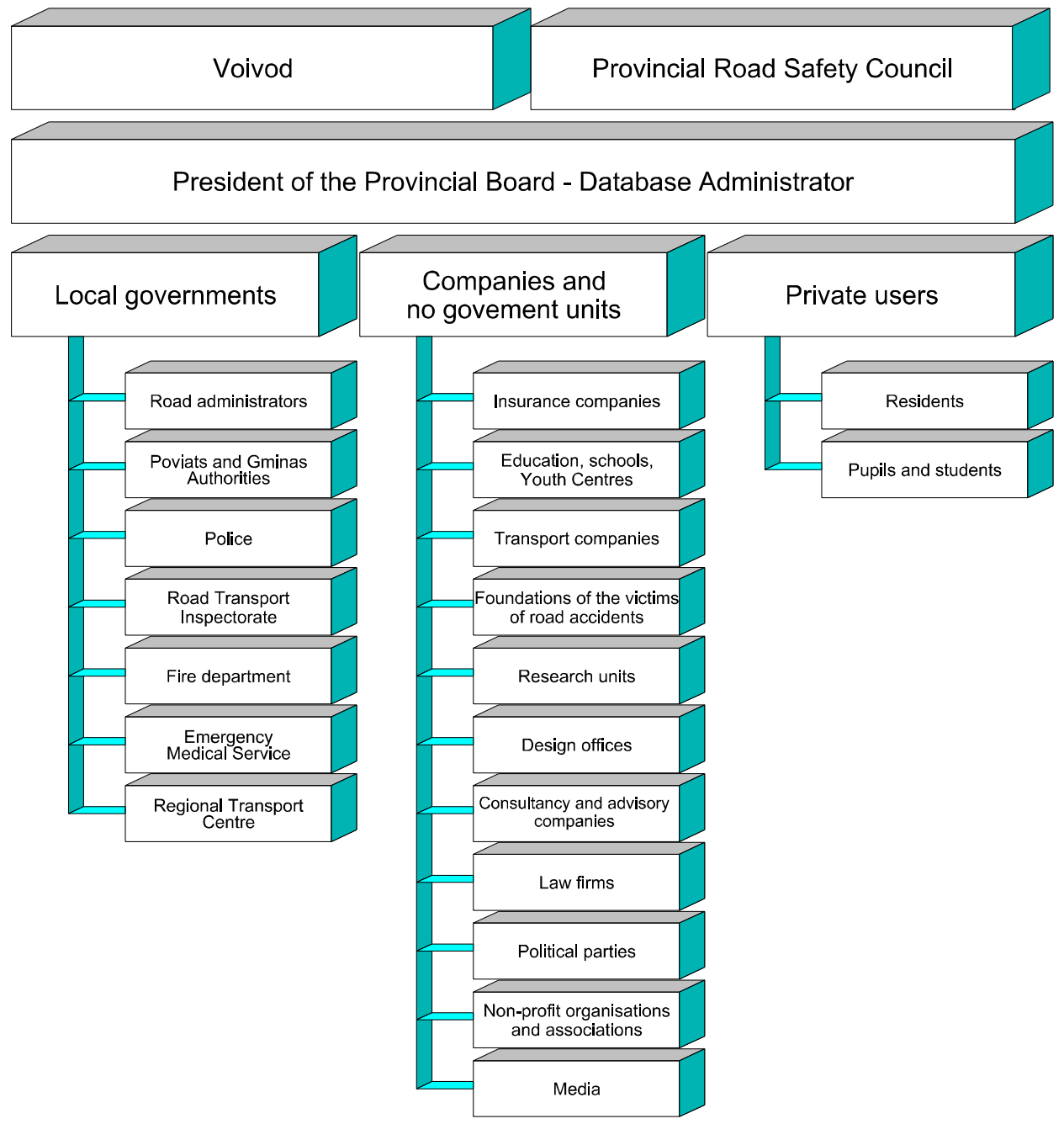

Fig.1 The schema of database groups of users (based on [6])

Rys. 1. Schemat grup użytkowników bazy danych (na podstawie [6]) 
i. scientists and researchers who study phenomena among infrastructure and road users, looking for solutions in legislation, organization and infrastructure that would enable to increase the safety level.

Knowledge of expectations among the potential IT system users makes it possible to determine a profile of the portal content. The fact of the continuous changes in the areas of interests and expectations of specific groups of portal users as well as developments in knowledge, technology and IT, enforce the creation of the option to develop the system with new functional areas that cannot be foreseen at the initial phase of the system development. Therefore, the constant monitoring of system user expectations is necessary. Moreover, the planned structure of the system will enable its future development with different elements to guarantee its attractiveness for all users.

\section{Content of IT System}

Considering the open architecture of solutions based on web portals [7] and their almost unlimited development potential, the scope of content in the road safety management IT system is unlimited. The actual content of the system will stem from its development based on needs resulting from the ongoing operations as well as the evolution of IT demands with regard to road safety and technique developments. At the initial phase of the system operation, the following thematic blocks have been planned:

1. news on road traffic, including the current disruptions in road traffic and actions carried out by the police and other traffic control authorities;

2. data on devices that support transport and road;

3. data on road incidents, including both accidents and road collisions that have been recorded by the police and/or by insurance;

4. data of the general road safety assessment for the system operation area including information on black spots in the road network, as the source of objective data on road safety for road administrators, traffic administrators, planners, local communities, politicians, and decision-makers;

5. data on the detailed road safety condition assessment for a selected area of the system operation including detailed characteristics of a road safety status, necessary for road and traffic authorities and organizations involved in road safety activity;

6. general data on roads and transport infrastructure, traffic, proposals of network development, as materials available also to local communities;

7. detailed data on roads infrastructure (including a complete record of roads and bridge facilities), as materials available to road authorities, being the tool to collect data on roads according to applicable law [3];

8. materials concerning programmes and campaigns in road safety;

9. data on behaviour of road users as a result of preventive actions taken by the police and other traffic control authorities;

10. materials concerning design solutions used to improve road safety and area development and planning; 
11. training materials in road safety for teachers at different levels, necessary to educate children and their parents as well as the elderly, drivers and to educate personnel involved in road safety;

12. legal materials - instructions, laws, standards and other documents;

13. the address database of institutions involved in the problems of road safety, trainings for drivers, courses for teaching personnel, assistance to accident victims, training in first aid etc.;

14. a list of magazines, books, specialist literature and links to other portals that concern similar issues;

15. a discussion forum that enables the exchange of information and comments concerning the matters of road safety and transport.

Furthermore, the system is also to provide that access to the portal road safety database, and thus to the detailed information, will require adequate authorizations [8] that should guarantee the reliability of data included in it. Therefore, depending on the privileges of portal users and their granted authorizations to access information, they will be able to use a different scope of data collected in the system. Owing to this assumption, it will be possible to develop the database by numerous entities involved in the road infrastructure and traffic (including road infrastructure authorities). On the other hand, it will make it possible to develop the possibility of the complete or partial self-financing of the portal. According to the plan, access to some data and materials will be paid, e.g. to certain training or design resources, traffic data and characteristics, detailed assessments of road safety, detail maps of traffic signing and road marking, selected data on road and bridges facilities etc. Moreover, the portal may be supplemented with commercial blocks as the another source of database self-funding.

\section{Summary}

The above guidelines for developing the IT system of road safety management have been proposed as a new concept of systemic solution used to improve road safety in the voivodship within the Gambit Kujawsko-Pomorski Programme. The obvious advantage is the fact that the IT solution is based on a transparent and clear internet portal, which enables its use in an intuitive and user-friendly manner. As an important opportunity for the IT system development, the broad range of its users has to be indicated, from local communities, through administration entities, and scientific centres, to businesses and designers, for whom the knowledge collected in the database, including examples of good practices, may be the source of inspiration in new solutions and may enable to co-finance the maintenance of the presented system. The introduction of the discussion forum module, where local citizens may express their opinions, observations, and suggestions, would facilitate the collaboration among entities responsible for road safety (road and local authorities) in improving the safety of their local communities. However, there are some hazards in the introduction of such IT solutions. The lack of suitable promotion of the proposed system, a low budget planned for its implementation, especially at 
the initial phase, negligence in updating content included in the system, as well as the potential technical problems during its implementation, may result in the low popularity of the proposed solution and, consequently, its natural closure. Finally, it has to be emphasized that according to the author, the implementation of the presented system and the care for its validity and development should be among the priorities of local government authorities, as the entity that is responsible for communal safety and health.

\section{Literature}

[1] OECD/ITF, Road Safety Annual Report 2015.

[2] http://bezpieczna-droga-torun.pl/ \{data dostępu 05-07-2016\}.

[3] Journal of Laws from 2005, No. 67, Item 582, Regulation by the Minister of Infrastructure of 16 February 2005.

[4] Directive 2008/96/EC Of The European Parliament And Of The Council of 19 November 2008 on road infrastructure safety management.

[5] Collective work edited by Szczuraszek T.: Diagnoza bezpieczeństwa ruchu drogowego. Gambit Kujawsko-Pomorski (T.I). Diamond Books. Bydgoszcz 2010.

[6] Collective work edited by Szczuraszek T.: Program poprawy bezpieczeństwa ruchu drogowego. Gambit Kujawsko-Pomorski (T.II). Diamond Books. Bydgoszcz 2012.

[7] Gotlib D., Iwaniak A. Olszewski R., Budowa krajowej infrastruktury danych przestrzennych w Polsce - harmonizacja baz danych referencyjnych, Katedra geodezji i fotogrametrii Akademia Rolnicza we Wrocławiu, Wrocław 2006.

[8] Kothuri R., Godfrind A., Beinat E.: Pro Oracle Spatial for Oracle Database 11g, Apress, 2007.

\section{ZAŁOŻENIA DO BUDOWY INFORMATYCZNEGO SYSTEMU ZARZADZANIA BEZPIECZEŃSTWEM RUCHU DROGOWEGO}

\section{Streszczenie}

W artykule przedstawiono rolę, potrzebę i idee zastosowanie informatycznego systemu do zarzadzania bezpieczeństwem ruchu drogowego będącego propozycją praktycznej implementacji elementów programu Gambit przygotowanej dla województwa kujawsko-pomorskiego. Przedstawiono celowość budowy takiego systemu, jego potencjalnych użytkowników oraz proponowaną zawartość i możliwość jego samofinansowania. Całość artykułu podsumowano wskazując na szanse oraz zagrożenia przy wdrażaniu omawianego systemu.

Słowa kluczowe: inżynieria ruchu drogowego, bezpieczeństwo ruchu drogowego, systemy IT

Przestano do redakcji: 07.06.2016 $r$.

Przyjęto do druku: 30.06.2016 r.

DOI: $10.7862 / \mathrm{rb} .2016 .72$ 